\title{
Asia's oceanic Anthropocene: How political elites and global offshore oil development moved Asian marine spaces into the new epoch
}

\author{
Stefan Huebner ${ }^{\dagger}(\mathbb{D}$ \\ Asia Research Institute, National University of Singapore, 119260 Singapore \\ E-mail: arihust@nus.edu.sg
}

\begin{abstract}
The Anthropocene epoch, characterized by human-caused planetary-scale transformations like climate change and ocean acidification, today is usually associated with the period beginning in the mid-twentieth century. Taking an oceanic perspective on the Anthropocene in Asia, the article argues that oceanic and terrestrial energy regimes synchronized since the 1950s when, for the first time in history, oceanic ghost acres turned marine spaces into a major fuel source. Despite global connections between offshore oil regions located in North America, Asia, and other places going back to the late nineteenth century, Asia's contingent offshore oil field locations and their physical geographies, combined with political factors, inhibited large-scale offshore drilling before the 1950s. These characteristics of marine spaces meant that Asian political elites and their developmentalist agendas became the guiding force in exploring offshore fields, a process that was hardly dominated by corporate capitalism or structural choice limitations due to the legacies of colonialism.
\end{abstract}

Keywords: Oil; ocean; Anthropocene; environment; Asia; Japan

\section{Introduction}

In Asia's Anthropocene, Asia's marine spaces have no narrative. The Anthropocene epoch refers to the new and growing human impact on biogeochemical cycles of planetary scale, such as climate change, ocean acidification, or atmospheric nuclear pollution. ${ }^{1}$ Today, the Anthropocene is usually associated with the period beginning in the mid-twentieth century. Incidentally, this is the time when fossil fuel development in Asia's part of the world ocean began to synchronize with the continent's terrestrial fossil fuel-based development projects. ${ }^{2}$ Since then, offshore oil and gas

\footnotetext{
'I would like to thank the Asia Research Institute (National University of Singapore), the Harvard University Asia Center, the SSRC (New York City) and its Transregional Research Junior Scholar Fellowship Program, and the SSRC (Singapore)'s Social Science Research Thematic Grants Program. I am also grateful to the three anonymous reviewers, Ashawari Chaudhuri for her careful reading of the text, and many colleagues who provided valuable comments at multiple events, in particular at the National University of Singapore, Harvard University, the German Historical Institute Washington, and the Association for Asian Studies Conference 2021.

${ }^{1}$ The United Nations began to officially use the term in late 2020, though more in a loose than a stratigraphic sense; see UNDP, ed., Human Development Report 2020. The Next Frontier: Human Development and the Anthropocene (New York: UN, 2020).

${ }^{2}$ Recent studies propose the Great Acceleration since the mid-twentieth century as the first stage of the Anthropocene: John R. McNeill and Peter Engelke, The Great Acceleration. An Environmental History of the Anthropocene since 1945 (Cambridge, MA: Harvard University Press, 2014); Will Steffen et al., 'The Trajectory of the Anthropocene: The Great Acceleration,' Anthropocene Review 2, no. 1 (2015): 81-98.

(c) The Author(s), 2022. Published by Cambridge University Press. This is an Open Access article, distributed under the terms of the Creative Commons Attribution licence (http://creativecommons.org/licenses/by/4.0/), which permits unrestricted re-use, distribution and reproduction, provided the original article is properly cited.
} 
drilling experienced a very strong expansion, even though more recently offshore wind turbines and floating solar panels have become central pillars of renewable energy development strategies in Asia and globally.

What can be called a first wave of humanities and social science publications on the Anthropocene largely shifted responsibility for climate change and other planetary-scale transformations to a small group of Euro-American economic elites: these economic elites set in motion the transatlantic capitalist economic system that the authors associate with New World plantation economies and exploitative slave labour regimes. Similarly, the Industrial Revolution's shift in modes of production was associated with the intention of British industrialists to reduce dependence on unruly labour. Plans to technologically reduce such dependence then gave birth to large-scale mechanization powered by water and steam in the Age of Coal. In this view, the Western path of fossil fuel-based technological development resulted over the long run in an exponential increase in fossil fuel consumption and the related emissions of greenhouse gases. Such claims - and the additional '-cenes' (capitalocene, plantationocene, etc.) that the authors coined-helped to spur research into the global origins of the Anthropocene. ${ }^{3}$ In view of the deficits of these claims-ranging from hardly addressing the ecological disasters caused by the planned economies of communist-ruled countries and a selective actor focus on a capitalist elite instead of consumers to a bias toward dynamics in Europe and the Americas-more recent studies began to locate Asia's place in the trajectory of the Anthropocene. A major contribution was Amitav Ghosh's The Great Derangement, written by one of Asia's most well-known novelists. ${ }^{4}$ His book drew attention to the missing narrative of climate change, which appears to be the most prominent problem of the Anthropocene, in global histories of Asia. Ghosh's book was thought-provoking, since he connected climate change to the results of the Great Divergence between Asian and Western economies. ${ }^{5}$ In Ghosh's view, colonialism inhibited Asia's industrialization and hence also prevented an earlier and therefore larger share in global greenhouse gas and other emissions. ${ }^{6}$ This claim, debatable as it is, draws attention to the developmentalist agendas of Asian postindependence governments. Over the course of decades, these governments drastically upscaled their countries' greenhouse gas-relevant fossil fuel consumption. Moreover, Asian political elites decided on their countries' post-independence technological trajectories and operated in a world shaped by global connections and disruptions, which shaped the respective regimes of fuel extraction and energy generation.

My article emphasizes that Asia's marine spaces still lack such an oceanic Anthropocene narrative. ${ }^{7}$ I propose to create one by focusing on the sudden synchronicity of terrestrial and oceanic transitions to oil economies, meaning the convergence of two once strictly separate temporalities, as a defining moment in the emergence of Asia's Anthropocene. Globally, the world ocean's transformation into a fossil fuel source was important, since regardless of whether its fuel products were burned offshore or on land, the emitted greenhouse gases eventually accumulated in the atmosphere. The greenhouse gases then influenced biogeochemical cycles that reconnected atmosphere, sea, and land, resulting not only in climate change but also in the warming,

\footnotetext{
${ }^{3}$ For a bias toward putting responsibility on corporate capitalism and, in particular, European and North American capitalists, see Andreas Malm, Fossil Capital: The Rise of Steam Power and the Roots of Global Warming (London: Verso, 2016); Naomi Klein, This Changes Everything: Capitalism vs. the Climate (New York: Simon \& Schuster, 2014). For three '-cenes,' see Donna J. Haraway, Staying with the Trouble. Making Kin in the Chthulucene (Durham: Duke University Press, 2016).

${ }^{4}$ Amitav Ghosh, The Great Derangement: Climate Change and the Unthinkable (Chicago: University of Chicago Press, 2016).

${ }^{5}$ See, in particular, Kenneth Pomeranz, The Great Divergence. China, Europe, and the Making of the Modern World Economy (Princeton: Princeton University Press, 2001).

${ }^{6}$ Ghosh, The Great Derangement, 109-10.

${ }^{7}$ If not otherwise stated, 'oceanic' refers to the world ocean including its littoral seas and is used interchangeably with 'marine.' The terms refer to spaces of saltwater or brackish water as opposed to terrestrial space.
} 
acidification, and related biodiversity decline of the ocean. ${ }^{8}$ Focusing on the historical origins of the oceanic Anthropocene, the article analyses the differences and connections in the trajectories of offshore oil drilling in Asia, the United States, and other places, which were shaped by local environmental and political factors that facilitated or inhibited the ability to discover and develop offshore oil fields. In the process of analysing Asian political elites, in particular cabinet members and senior bureaucrats, as the main guiding force of offshore fossil fuel development projects in Asian waters, I expand this new oceanic Anthropocene narrative to start a dialogue with recent studies on the global histories of development, the environment, and technology: in its temporal dimension, the analysis ranges from the first offshore wells drilled during the 1880s to decolonization, the Cold War, and the United Nations' first and second 'Decades of Development' in the 1960s and 1970s. In its spatial dimension, the analysis transgresses the horizontal focus usually associated with terrestrial history and addresses transformations taking place on the oceanic surface but also in spaces deep below it. Geographically, the sites of analysis stretch from the Persian Gulf in West Asia to the South China Sea in Southeast Asia and further north to the East China Sea and the Sea of Japan in East Asia. Such an oceanic perspective is necessary since recent global histories of development, the environment, and technology-as well as modern histories of Asia in the world—still overlook Asia's marine spaces. ${ }^{9}$ Even if more environment-focused studies go beyond terrestrial boundaries and touch on oceanic development questions, they usually focus on overfishing, overhunting, or other unsustainable practices. ${ }^{10}$ While important, most of these processes did not mark planetary-scale disruptive shifts toward the oceanic Anthropocene in Asia. Ocean-related research gaps are thus wide-spread, despite the huge extent of human-built marine structures, such as marine agriculture (mariculture) facilities, offshore platforms, or coastal protections. The structures' impact has modified an estimated 1 to 3.4 million $\mathrm{km}^{2}$ of ocean space (which is roughly equivalent to the size of global urban land cover), and the majority of them are located in coastal Asia. ${ }^{11}$ In a broader sense, this article also adds an oceanic perspective to the growing analytical attention paid by global historians to the environmental conditions and ecological footprints of changing energy regimes during the long nineteenth century's Great

\footnotetext{
${ }^{8}$ Jan Zalasiewicz and Mark Williams, 'The Anthropocene Ocean in its Deep Time Context,' in The World Ocean in Globalisation: Climate Change, Sustainable Fisheries, Biodiversity, Shipping, Regional Issues, eds. Davor Vidas and Peter J. Schei (Leiden: Martinus Nijhoff Publishers, 2011), 19-35.

${ }^{9} \mathrm{~A}$ study of Indonesian oil development does not mention offshore oil in a single sentence: Eric. G. Dinmore, 'The Hydrocarbon Ring: Indonesian Fossil Fuel, Japanese "Cooperation", and US Cold War Order in Asia,' in Engineering Asia. Technology, Colonial Development, and the Cold War Order, eds. Hiromi Mizuno, Aaron S. Moore, and John DiMoia (London: Bloomsbury, 2018), 113-36. Moore's important study of Japanese developmentalism also does not address the ocean: Aaron S. Moore, Constructing East Asia. Technology, Ideology, and Empire in Japan's Wartime Era, 1931-1945 (Stanford: Stanford University Press, 2013). Lorenzini's global history of development aid very helpfully expanded the focus to socialist countries, including China, but the ocean is missing: Sara Lorenzini, Global Development. A Cold War History (Princeton: Princeton University Press, 2019). The same is true for Bayly's global history of the modern world: Christopher A. Bayly, Remaking the Modern World, 1900-2015. Global Connections and Comparisons (Hoboken: John Wiley, 2018).

${ }^{10}$ See the Asia-related chapters in David Armitage, Alison Bashford, and Sujit Sivasundaram, eds., Oceanic Histories (Cambridge: Cambridge University Press, 2017). On the development of Japanese fisheries to finance Japanese imperialism, see William Tsutsui, ‘The Pelagic Empire: Reconsidering Japanese Expansion,' in Japan at Nature's Edge. The Environmental Context of a Global Power, eds. Ian J. Miller, Julia A. Thomas, and Brett L. Walker (Honolulu: University of Hawai'i Press, 2013), 21-38; Nadin Heé, 'Tuna as an Economic Resource and Symbolic Capital in Japan's 'Imperialism of the Sea," in Animals and Human Society in Asia: Historical and Ethical Perspectives, eds. Rotem Kowner et al. (Cham: Springer, 2020), 213-38. A recent study on aquatic Asia addresses several development projects but leaves out offshore oil: Sunil Amrith, Unruly Waters: How Rains, Rivers, Coasts, and Seas Have Shaped Asia's History (New York: Basic Books, 2018).

${ }^{11}$ The largest impact is associated with China, South Korea, and the Philippines: Ana Bugnot et al., 'Current and Projected Global Extent of Marine Built Structures,' Nature Sustainability 4 (2021): 33-41.
} 
Transformation and, now usually seen as the first stage of the Anthropocene, the post-1950s Great Acceleration. $^{12}$

The local environmental conditions of Asian marine spaces in combination with political factors and the related agency of Asian political elites explain why and how oceanic and terrestrial energy transitions began to synchronize in the 1950s in the Asian Anthropocene. The article's main argument is that Asian political elites and their developmentalist agendas-meaning governmental economic planning projects-were the guiding force in appropriating Asian marine spaces and exploiting offshore oil fields during post-WWII decolonization. Neither a small group of exploitative Western or transnational corporate capitalists nor structural choice limitations due to the infrastructural and judicial legacies of colonialism were responsible. Contingent geographical locations of oil fields and their largely unfavourable physical geographies (such as local coastal and oceanic environmental conditions, ranging from water depths to monsoon impacts) were the initially inhibiting factors that, I argue, connected the offshore fossil fuel development projects to the strong agency of Asian political elites. Locations and related physical geographies, combined with political factors, created a divergence from developments in the United States and other places that largely inhibited offshore oil drilling in Asian marine spaces before the 1950s, the point in time when almost all the Asian political entities that will be discussed here had gained independence. When open waters offshore oil technology from the United States became broadly available at about that time, Asian marine spaces were accessible by drilling barges, offshore platforms, or tankers, whereas terrestrial development projects were strongly shaped by whether Western or Japanese colonialism had resulted in the construction of transportation and other physical infrastructures. In a nutshell, the Asian political elites' agency regarding marine spaces was, in contrast to terrestrial sites, hardly affected by any structural choice limitations related to physical infrastructure legacies. The same is true for polity-related structural choice limitations, since marine spaces outside of territorial waters were largely unaffected by global or domestic legal structures created during colonialism. Asian political elites therefore were the guiding force in the appropriation of the oil deposits of Asia's continental shelf (meaning the offshore extension of the continental landmass) by newly claiming sovereignty over them. Aiming to decolonize economic structures established during colonialism, they in many cases also created national oil companies with whom private transnational companies had to collaborate, which further enhanced state control over offshore oil drilling. Offshore oil technology also allowed decentralized production, which usually operated in a framework of governmental legislation that divided state-controlled waters into individual leases (not permanent sales). However, despite this more atomized mode of production, Asian political elites still insisted on their initiative and increased state control or established state monopolies. These characteristics of Asian marine spaces therefore connect the (otherwise very heterogenous) group of Asian political elites. Their strongly intertwined offshore fossil fuel developmentalisms, which included economic and military concerns as well as a lack of trust in foreign oil companies, are what here constitute these (primarily) cabinet members and senior bureaucrats as a group. Offshore oil was part of their industrial policies, resource securement plans, and trade policies. Moreover, it was related to, though not an integral part of, broader strategies of physical infrastructure development, such as expanding ports and the shipping industry, which facilitated the import or export of oil and also depended on it as a fuel.

\footnotetext{
${ }^{12}$ Here again, while important, most studies take a strong terra-centric perspective: John Brolin and Astrid Kander, 'Environmental Factors in Trade during the Great Transformation: Advancing the Geographical Coverage before 1950,' Journal of Global History 15, no. 2 (2020): 245-67; Prasannan Parthasarathi, Why Europe Grew Rich and Asia Did not: Global Economic Divergence, 1600-1850 (Cambridge: Cambridge University Press, 2011), in particular 151-82; Paolo Malanima, 'Energy Crisis and Growth 1650-1850: the European Deviation in a Comparative Perspective,' Journal of Global History 1, no. 1 (2006): 101-21; Eric L. Jones, The European Miracle: Environments, Economies and Geopolitics in the History of Europe and Asia. $3^{\text {rd }}$ ed. (Cambridge: Cambridge University Press, 2003), 81 (where fisheries creating ghost acres are mentioned but the discussion is limited to four sentences). McNeill and Engelke, The Great Acceleration, has a stronger oceanic focus, primarily addressing climate change implications, whaling, and overfishing.
} 
The high oil demand of the contemporary Japanese economy, connecting it to other Asian countries and accelerating offshore exploration and production, will guide the analysis and the selection of Asian marine regions from the Indian and Pacific Oceans that will be discussed here.

By transgressing terrestrial perspectives, the article increases our understanding of the role of Asian political elites in moving part of the world ocean into the Anthropocene, the corresponding changes in terrestrial and oceanic energy regimes, and the relationship between the globalization of technological advances, contingent geographical locations of oil fields, and related local physical geographies. In that sense, the article highlights the strong changes in Asian political elites' agency before and after the 1950s. Elizabeth Chatterjee's recent study on electrical grids and 'fossil developmentalism' in Asia-mostly India and China-also investigated the agency of political elites after the end of empire, emphasizing their state-led moral projects of democratizing energy consumption as an important reason for Asia's growing greenhouse gas emissions and the emergence of the Asian Anthropocene. ${ }^{13}$ I agree with her argument in a general sense. However, the terracentric perspective aside, the example of electric grids is very problematic when used to emphasize the strong agency and fossil fuel development agendas of Asian political elites. After all, until electricity from renewable sources became a marketing object rather recently, the quality of electricity did not differ between producers, unlike in the case of almost any other commodity, and differences, such as in voltage, would have been a competitive deficit rather than a benefit. The very limited number of power plants in the centralized grid, high upfront investment costs, long construction periods, and other barriers to entry meant that such market conditions hardly encouraged competition and very likely resulted in a natural monopoly or oligopoly. ${ }^{14}$ The few attempts to create a decentralized power generation structure, such as Mao Zedong's biogas digester campaign during the 1970s, were highly experimental and almost completely abandoned as soon as possible. ${ }^{15}$ The military importance of electrical grids and the need to purchase or expropriate private land or use national park land to build connection lines all emphasize that private companies would encounter extreme challenges and that strong governmental involvement over almost all of the globe was no voluntary decision. ${ }^{16}$ Grid extension to 'remote' places even despite economic infeasibility is the strongest evidence for Chatterjee's argument regarding a moral project, but even today nationwide access is not fully realized in numerous Asian countries, as she confirms. ${ }^{17}$ Altogether, such electric grids exemplify that on land the agency of Asian political elites was drastically more inhibited by structural choice limitations originating in colonial legacies or infrastructural and technological systems than was the case for the marine spaces that will be investigated here.

\section{The materiality of offshore oil fields and Asian energy regimes}

A brief longue durée history of changing energy regimes in terrestrial and oceanic Asia, analysed within the framework of global changes in energy regimes, will emphasize the crucial importance of the period between the 1890s and the 1970s for Asian political elites in developing offshore oil fields into 'powerful' contributors to the oceanic Anthropocene. An energy transition can be defined as the gradual shift from a specific pattern of energy provision to a new state of an energy system. ${ }^{18}$ While such energy transitions constitute global phenomena, their impacts, speeds, and

\footnotetext{
${ }^{13}$ Elizabeth Chatterjee, 'The Asian Anthropocene: Electricity and Fossil Developmentalism,' Journal of Asian Studies 79, no. 1 (2020): 3-24.

${ }^{14}$ For a very critical overview of the bureaucratic results of centralized grid technology in the United States, see Amory B. Lovins, 'Energy Strategy: The Road not Taken?,' Foreign Affairs 55 (1976): 65-96. For strong criticism of Lovins, see Vaclav Smil, Energy Myths and Realities: Bringing Science to the Energy Policy Debate (Washington: AEI Press, 2010), 44-54.

${ }^{15}$ Smil, Energy Myths, 50.

${ }^{16}$ On such problems in Britain, which can also be found in Asian and other countries, see Katrina Navickas, 'Conflicts of Power, Landscape and Amenity in Debates over the British Super Grid in the 1950s,' Rural History 30 (2019): 87-103.

${ }^{17}$ Chatterjee, 'The Asian Anthropocene,' 18.

${ }^{18}$ Vaclav Smil, Energy Transitions: History, Requirements, Prospects (Santa Barbara: Praeger, 2010), vii.
} 
fuel mixes strongly differed locally. ${ }^{19}$ The long period before the onset of the Anthropocene in the middle of the twentieth century saw several such global energy transitions. Terrestrial ones ranged from the mastering of fire to the use and cultivation of plant biomass as fuels, such as in the form of wood and charcoal; the tapping of animal muscle power, turning animals into prime movers; since the eighteenth century the transitions from biomass to fossil fuels and from animate to inanimate, mechanical prime movers, such as steam engines; followed today by a transition from fossil fuels to renewable energy, such as wind and solar energy. ${ }^{20}$ Most importantly, Asia's marine spaces lacked the specific flora and fauna that defined Asia's terrestrial pre-fossil fuel economies. In terrestrial Asia, domesticated animals - among them cattle, horses, goats, Arabian and Bactrian camels, donkeys, water buffalos, yaks, Bali cattle, and gayals-or tamed ones like elephants were central elements in the energy regimes of these pre-fossil fuel economies. ${ }^{21}$ While carps and other sweet water fish were domesticated, though not as prime movers, the same did not happen to any big marine mammals, such as whales, therefore preventing a marine equivalent to terrestrial husbandry of prime movers or the use of their dung as biofuel. ${ }^{22}$ Capture fisheries and whaling during the early nineteenth century became rampant with the arrival of Western whaling ships in Asia's West Pacific waters. For decades, whaling ships commercially extracted large amounts of an actual oceanic biofuel, whale oil, until cheaper lamp oils increasingly displaced it during the second half of that century. ${ }^{23}$ In contrast, seaweed farming as a form of mariculture remained confined to a few shallow coastal regions, and seaweed species were not used as and further bred into a biofuel, unlike terrestrial plants. ${ }^{24}$ Moreover, watermills that existed since ancient times and were powered by river flows, like later hydroelectric dams, did not find equivalents in the ocean, where the energy of currents could not be harnessed, except by ships. ${ }^{25}$ Such ships also tapped offshore wind power, which windmills could not yet utilize. Altogether, if seen from the perspective of terrestrial energy transitions, Asian marine spaces remained in the very early stage of a biomass, pre-fossil fuel economy until the late nineteenth century - and many of them decades longer. A few had experienced a temporary peak in whale oil extraction, long after the invention of fire. However, suddenly, further emphasizing the different oceanic temporality, many Asian marine spaces skipped the millennia-long terrestrial transition of utilizing more biofuels and tapping animal muscle power. They also left out the first part— the Age of Coal—of the new and increasingly global fossil fuel economy. Instead, they rushed to the exploitation of offshore oil and into the Asian Anthropocene.

Energy transitions are closely entangled with technological advances and new imaginations of economy and society. To understand the consequences of the tremendous changes in terrestrial energy regimes that Asian political elites were eager to set into motion during decolonization, one

\footnotetext{
${ }^{19}$ Ian J. Miller and Paul Warde, 'Energy Transitions as Environmental Events,' Environmental History 24, no. 3 (2019): 464-70. On the early transition from coal to oil in oil-rich countries in North America and Europe, see Nuno L. Madureira, 'Oil in the Age of Steam,' Journal of Global History 5, no. 1 (2010): 75-94.

${ }^{20}$ Smil, Energy Transitions, 1, 25, 149.

${ }^{21}$ Jared Diamond, Guns, Germs, and Steel. The Fates of Human Societies (New York: Norton, 2005), 158-63.

${ }^{22}$ On the substantial impact of whale feces on marine ecosystems, see Joe Roman and James J. McCarthy, 'The Whale Pump: Marine Mammals Enhance Primary Productivity in a Coastal Basin,' PLoS One 5, no. 10 (2010): 1-8.

${ }^{23}$ Jakobina K. Arch, Bringing Whales Ashore. Oceans and the Environment of Early Modern Japan (Seattle: University of Washington Press, 2018); Ryan T. Jones, 'Running into Whales: The History of the North Pacific from below the Waves,' American Historical Review 118, no. 2 (2013): 349-77.

${ }^{24}$ In Japan, some limited seaweed farming had taken place for centuries; see Roderick I. Wilson, 'Placing Edomae: The Changing Environmental Relations of Tokyo's Early Modern Fishery,' Resilience 3 (2015-2016): 242-89, especially 251-5. However, the life history of Porphyra ssp., in Japan known as nori, was understood only after WWII, when large-scale farming there and in China began; see Peter Neushul and Zuoyue Wang, 'Between the Devil and the Deep Sea: C. K. Tseng, Mariculture, and the Politics of Science in Modern China,' Isis 91, no. 1 (2000): 59-88, here 76-81.

${ }^{25}$ Smil, Energy Transitions, 51, 110-12.
} 
needs to realize the connection to the ocean as a fuel provider. Until the end of the nineteenth century, the ghost acreage that marine spaces contributed to fuel production was limited to the aforementioned short peak in whale oil production. Ghost acres here refer to the additional acres gained by a country through outsourcing commodity production overseas, such as the food and raw materials produced in the British Empire for consumption or processing in Britain, as analysed, for example, by Kenneth Pomeranz. ${ }^{26}$ Simultaneously, one of the major factors for Britain's Industrial Revolution and one origin of the Anthropocene was the use of fossil fuels to escape the Malthusian environmental-spatial constraints of a biofuel economy. The pressure of continuous deforestation and wood scarcity that peaked in Britain in the eighteenth century was lessened through the increasing use of coal fields or 'subterranean forests', as Rolf P. Sieferle called them. ${ }^{27}$ Globally, the British economy's need to use coal as a forest substitute put it into a special position. The demand for large amounts of coal and the favourable contingency of field locations, making them easily accessible, then constituted an important environmental-geographical difference to, for example, precolonial India, still in possession of large forests, or China, characterized by large distances between major coal fields and population centres. ${ }^{28}$ According to Vaclav Smil's calculations in 2010, supplanting the global total power generated by fossil fuels that year with plant biomass in order to become carbon-neutral would require at least $12,500,000 \mathrm{~km}^{2}$ of barrier-free land (not to mention fertilizer and water) for industrial forestry. ${ }^{29}$ This spatial demand is roughly an equivalent of the entire territories of the United States and India. Accordingly, Asian countries' growing use of energy-dense fossil fuels since the nineteenth century was based on subterranean space that substituted demand for forest space. Returning to the ghost acres, offshore oil fields, completely dwarfing the amounts of whale oil extracted from the ocean, for the first time in history created a vast expanse of oceanic ghost acres which substituted demand for forest space. Consequently, when oceanic ghost acres of offshore oil became available, they did decrease fuel-related environmental pressure on terrestrial space. ${ }^{30}$ The ocean hence went far beyond the provision of nutrition ghost acres. It began to provide Asian countries with amounts of energy that, due to physical space constraints, one can hardly imagine being generated by terrestrial industrial forestry or biofuel farming. Many Asian countries during the 1960s and 1970s still relying on biomass fuels, which accelerated deforestation and other problems, therefore supported their political elites' interest in offshore oil exploration and use. Around the end of the period investigated here, in 1975, the share of offshore oil in total production varied widely among Asian countries, but in several cases it had become very substantial (see Table 1). Information on numbers of offshore platforms, their exact locations, and production amounts are scarce due to national security concerns and maritime boundaries conflicts, but also illustrate a strong rise in numbers (see Table 2). Asian political elites appropriating marine spaces that harboured

\footnotetext{
${ }^{26}$ Pomeranz, The Great Divergence, 7, 274-8, 313-5.

${ }^{27}$ Rolf P. Sieferle, The Subterranean Forest. Energy Systems and the Industrial Revolution (Cambridge: White Horse Press, 2001).

${ }^{28}$ Parthasarathi, Why Europe Grew Rich, 151-82; Pomeranz, The Great Divergence, 49, 61-8, 307-12.

${ }^{29}$ Smil, Energy Transitions, 111-7. The necessary amount of power would be about 12.5 terawatts.

${ }^{30}$ Different types of carbon fuels like wood and oil were and are partially interchangeable, and physical space constraints indeed created important boundaries. One drastic example is that when WWII ended, the Japanese colonizers had deforested nearly three-quarters of Korea's forest cover. Forest products served various military and industrial demands, but producing fuel for popular heating, transportation purposes, etc., was also an important factor. For example, since gasoline was limited to military use after 1941, the engines of many vehicles were converted to (inefficient) wood-burning ones. See David Fedman, Seeds of Control. Japan's Empire of Forestry in Colonial Korea (Seattle: University of Washington Press, 2020), 6, 200-22. In this example, wood, the production of which was constrained by physical space, had to substitute for the lack of oil, resulting in unsustainable devastation of forests. For European examples, see Sieferle, The Subterranean.
} 
Table 1. Offshore crude oil production

\begin{tabular}{|c|c|c|c|}
\hline \multicolumn{4}{|c|}{ Offshore crude oil production (thousand bbls/day) } \\
\hline Year & 1970 & 1973 & 1980 \\
\hline World (total) & $\sim 7,532.0$ & $\sim 10,445.59$ & $13,687.49$ \\
\hline Saudi Arabia & $1,251.0$ & $1,990.4$ & $2,958.00$ \\
\hline Abu Dhabi & 269 & 454.43 & $1,322.01$ \\
\hline Indonesia & 32 (in 1971) & 174.22 & 533.05 \\
\hline $\begin{array}{l}\text { Neutral Zone (Divided Zone) } \\
\text { between Saudi Arabia and } \\
\text { Kuwait }\end{array}$ & 380 (in 1971) & 394.04 & 403.00 \\
\hline Dubai & 70 & 221.49 & 344.95 \\
\hline Malaysia & $146^{\mathrm{a}}$ & $264.16^{\mathrm{a}}$ & 280.32 \\
\hline Qatar & 172 & 378.31 & 247.55 \\
\hline Brunei & $146^{\mathrm{b}}$ & $264.16^{b}$ & 192.24 \\
\hline Iran & 322 & 452.41 & 150 \\
\hline India & N/A & $\mathrm{N} / \mathrm{A}$ & 142.14 \\
\hline Sharjah & $\mathrm{N} / \mathrm{A}$ & $\mathrm{N} / \mathrm{A}$ & 10 \\
\hline Philippines & $\mathrm{N} / \mathrm{A}$ & $\mathrm{N} / \mathrm{A}$ & 4 \\
\hline China & $\mathrm{N} / \mathrm{A}$ & $\mathrm{N} / \mathrm{A}$ & 2 \\
\hline Japan & 3 & 1 & 1.53 \\
\hline \multicolumn{4}{|c|}{ Share of offshore crude oil production in total crude oil production (global) } \\
\hline 1973 & 1980 & 2005 & 2015 \\
\hline$\sim 20 \%$ & $22,88 \%$ & $32 \%$ & $29 \%$ \\
\hline
\end{tabular}

aTogether with Brunei.

${ }^{\text {b}}$ Together with Malaysia.

Sources: 'Offshore Crude Production', Offshore (20 June 1975): 84; Kato Masakazu, 'Present and Future of Offshore Petroleum Developments', in The Ocean Association of Japan (ed.), Exclusive Economic Zone, 1982: Proceedings of the $7^{\text {th }}$ International Ocean Symposium, October 21-22, 1982 (Tokyo: The Ocean Association of Japan, 1983), 73-80; K. O. Emery, 'Economic Placer Deposits of the Continental Shelf', Offshore (March 1969): 91-105; 'Will Environment Opposition Lessen?' Offshore (December 1973): 77-78; 'Offshore Production Nearly 30\% of Global Crude Oil Output in 2015', https://www.eia.gov/todayinenergy/detail.php?id=28492, accessed 8 September 2021.

Asia's offshore fields thus created an important oceanic substitute for an otherwise much higher demand for terrestrial fuel sources, depending on where countries and markets were situated in the transition between biomass, coal, and oil.

When discussing the materiality of marine spaces and offshore oil fields, the main factor that globally enabled the offshore energy transition was the liquidity of oil, flowing because of gas pressure or artificially induced pressure toward an extraction point drilled from above the aquatic surface into the seabed. In contrast, the physical properties of aquatic spaces do not enable an economically feasible extraction of coal, it being solid and therefore too immobile. The ocean thus never saw an energy transition to coal. In the same way, the liquidity of oil facilitated loading and unloading of tankers and allowed the use of offshore pipelines that connected platforms and terrestrial infrastructures, while the bulkiness of coal did not result in the creation of such an offshore pipeline infrastructure. Likewise, the physical properties of the ocean meant that offshore oil geographies were accessible due to the aforementioned limited need for infrastructure construction compared to land. As early offshore oil production in the United States' Mississippi River Delta, Burma's Irrawaddy River, and other places will illustrate, aquatic spaces enabled the movement of ships and barges carrying exploration and production equipment, followed later by tankers. In contrast, operating in terrestrial regions unconnected by road or rail and without local market demand entailed prohibitive financial costs, meaning that even in the case of terrestrial oil exploration and production, coastlines and rivers were very important geographical access, export, and supply nodes. In Asia, the locations of oil fields and related physical geographies thus strongly shaped the history of when Asian political elites began to tap oceanic ghost acres. 
Table 2. Mobile and production platforms

\begin{tabular}{|c|c|c|c|c|c|c|c|c|}
\hline \multirow[b]{2}{*}{ Date } & \multicolumn{4}{|c|}{ Mobile platforms (usually used for exploration purposes) } & \multicolumn{2}{|c|}{$\begin{array}{c}\text { Production } \\
\text { platforms }\end{array}$} & \multicolumn{2}{|c|}{$\begin{array}{l}\text { Platforms total } \\
\text { (mobile and } \\
\text { production) }\end{array}$} \\
\hline & April 1974 & April 1975 & July 1978 & 1981 & 1975 & 1978 & 2010 & 2015 \\
\hline Southeast Asia & 24 ( +1 idle, 1 en route) & 38 & 31 (+6 idle) & See below & & & $1,278-1,380^{\mathrm{a}}$ & $\sim 1,082^{b}$ \\
\hline Middle East & $30(+1$ en route) & $34(+1$ idle $)$ & 42 (+2 idle, 1 en route) & 63 & & & & $\sim 2,346$ \\
\hline Global & 210 ( +30 idle, 8 en route) & 274 ( +13 idle, 2 en route) & 356 (+39 idle, 7 en route) & & & & & \\
\hline Japan & 2 & 1 & $2(+2$ idle $)$ & 1 & & & & \\
\hline Indonesia & & & & 21 & 32 & 102 & & \\
\hline PRC & & & & 15 & & & & \\
\hline India & & & & 7 & & 4 & & \\
\hline Malaysia & & & & 8 & & & & \\
\hline Brunei & & & & 2 & & & & \\
\hline North Korea & & & & 1 & & & & \\
\hline Philippines & & & & 4 & & 0 & & \\
\hline Taiwan & & & & 1 & & 0 & & \\
\hline Thailand & & & & 3 & & & & \\
\hline Pakistan & & & & & & 1 & & \\
\hline Abu Dhabi & & & & & & 93 & & \\
\hline Qatar & & & & & & 3 & & \\
\hline
\end{tabular}

a South China Sea and further Chinese and Indonesian waters.

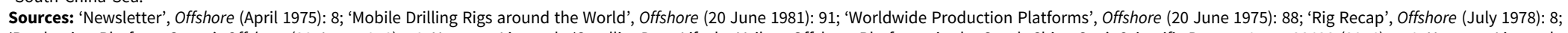

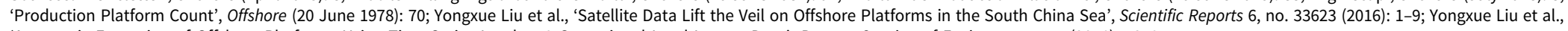

'Automatic Extraction of Offshore Platforms Using Time-Series Landsat-8 Operational Land Imager Data', Remote Sensing of Environment 175 (2016): $73-91$. 


\section{The development of early Japanese offshore oil production in a global context}

Japan is arguably one of the first countries in which offshore oil drilling took place. ${ }^{31}$ Historical records show that at least since the seventh century, very limited oil harvesting had taken place in Echigo Province (now Niigata Prefecture) in central-west Honshu. During the late nineteenth century, when industrial and consumer demand for oil increased, the terrestrial part of the region experienced an oil field exploration boom. In the early 1880s, an oil seepage was spotted by chance in the Sea of Japan, 40 to 50 metres off the coastal town of Amase (尼瀬, now part of Izumozaki) ${ }^{32}$ Such bubbling of oil, usually indicating gas pressure-driven releases from offshore oil fields, is a geological phenomenon that during the nineteenth century was already globally known, even though the usual reason (cracks in the seabed caused by seismic activity) was not. ${ }^{33}$ Rightly deducing the presence of offshore oil near Niigata Prefecture's terrestrial wells, Japanese oil companies during the late 1880 s created several extraction spots through reclamation of small islands, followed by the use of caissons to keep water out of the mining sites and hand-digging to the oilbearing strata. The early 1890s saw an expansion of this simple offshore oil infrastructure. Consultation of an advisor from the United States resulted in the use of mechanized drilling rigs and anti-flooding technology, allowing deeper and more productive drilling. ${ }^{34}$

The geographical contingency of Japan's coastal and offshore oil fields, resulting in unfavourable physical geographies, became a major reason why offshore oil drilling was not strongly pushed by Japanese political elites, such as members of the government or senior bureaucrats, until after WWII. There was no continuous stretch of fields from very shallow standing waters to deeper open waters, as for example in the United States' Mississippi River Delta, where such conditions constantly advanced offshore oil technology. Considering the growing Japanese demand for oil during the imperial period, a local market existed, in contrast to several places analysed later. Without the inhibiting geographical contingency of field locations, the divergence between the ability of Japanese and US experts to exploit offshore oil fields could have been smaller and the energy transition in Asia's waters pushed earlier by Japanese political elites. My point is that in the very late nineteenth century, when offshore oil drilling had emerged in both Honshu and Southern California, a related trans-Pacific technology transfer facilitated the Japanese offshore oil expansion. However, the geographical locations of Japanese fields later inhibited it. In 1894, as a result of many gas seepages, oil drilling began along Summerland's beach, a coastal county in Southern California close to Santa Barbara. During the following years, derricks were erected in flood tides. Finally, in spring 1898, the Southern Pacific Railroad built a first wooden pier reaching about 7.5 metres into Pacific waters at low tide, on which derricks were set up. The pier marked the beginning of US offshore oil drilling in marine waters. ${ }^{35}$ In 1902, more than one hundred such offshore oil wells were in operation in Summerland. This offshore advance by several private companies resulted in experiments to adapt drilling technology to aquatic conditions. Sand beaches provided challenges such as subsidence, well flooding, and other drilling disasters. Wooden pilings were usually used at locations that had been selected as harbours

\footnotetext{
${ }^{31}$ The point here is not to create a hierarchy who came first. On the Baku Khanate's Caspian waters (1803) and Grand Lake St. Marys in Ohio (late 1880s), see M.F. Mir-Babaev, Kratkâia khronologiia istorii azerbaìdzhanskogo neftianogo dela. Brief Chronology of the History of Azerbaijan's Oil Business (Baku: Sabakh, 2004), 151; B.A. Wells and K.L Wells, 'Ohio Offshore Wells,' https://aoghs.org/offshore-history/ohio-offshore-wells, accessed 20 March 2021.

${ }^{32}$ Yasuoki Noguchi, Chiri shashinchō. Naikoku no bu dai-2 chitsu [Geographic Photo Album. Domestic Part, Vol. 2] (Tokyo: Tōyōsha, 1900), 10.

${ }^{33 ‘}$ An Ocean Oil Well,' Scientific American (24 April 1886): 263; 'Drilling Wells off Shore in Texas Bays and Inlets,' Oil and Gas Journal (14 April 1938): 112-4, 117-8.

${ }^{34}$ Noguchi, Chiri shashinchō, 10; A. B. Waters, 'Japan Stepping up Drilling Program and Conservation,' World Oil 143, no. 6 (1956): 203-5.

${ }^{35}$ Alan Grosbard, 'Treadwell Wharf in the Summerland, California, Oil Field: the First Sea Wells in Petroleum Exploration,' in Discoverers of the 20th Century: Perfecting the Search, eds. Charles A. Sternback, Marlan W. Downey, and Gerald M. Friedman (Tulsa: American Association of Petroleum Geologists, 2005), 40-62, here 46-8.
} 
because of calm waters, not due to the presence of oil fields, but now had to withstand stronger impacts from waves, storms, and shipworms. ${ }^{36}$ Back at Amase beach, secure access to the offshore drill sites was improved around 1900 by changing from small pathways of reclaimed land, which could easily be eroded by water movements or storms, to the use of Summerland-like wooden piers. ${ }^{37}$ At the end of the nineteenth century, the offshore oilscapes created by private companies in Niigata Prefecture and Southern California thus were not genuinely different (see Figures 1 and 2).

During the first half of the twentieth century, offshore oil drilling increasingly diverged between Japan and those regions with field locations and physical geographies that encouraged a continuous technological expansion from standing to open waters. The physical geography of the United States' Mississippi River Delta and a few other places adapted offshore oil technology to increasingly deeper and rougher waters. From the mid-1920s, the application of new geophysical surveying technology provided more precise information on geological formations and potential oil fields. It accelerated exploration of the shallow, standing waters and tidal marshes of Louisiana's bayous in the Mississippi River Delta, resulting in a southern expansion of aquatic drilling. In 1938, offshore oil exploration entered the bays of the Gulf of Mexico. In the process, US oil companies designed steel pilings for deeper waters, concrete caissons against water intrusions into wells, and barges hosting dredges that dug canals between bayous, which were used by submersible drilling barges hosting derricks, supported by barges providing mobility to diesel electric generators, radio equipment, and worker accommodations. ${ }^{38}$ Oil companies also circulated such technologies between regions with analogous physical geographies, which were therefore all accessible with ships, including Pacific and other beaches and waters (coastal Peru, Brunei, California, Brazil, and Egypt), shallow and largely enclosed waters (Venezuela's Lake Maracaibo), or rivers (Burma's Irrawaddy). ${ }^{39}$ Returning to the Japanese empire, the absence of oil field locations featuring physical geographies similar to the Mississippi River Delta's bayous meant that Japanese political elites for decades had no reason to pay attention to potential fields in deeper waters. Nippon Oil Co. (Nihon Sekiyu K.K.), which dominated about 80\% of Japanese domestic oil production, certainly contributed to this lack of attention by shifting its focus during the early twentieth century from exploration work to refining imported oil. ${ }^{40}$ The critical point is that when environmental differences began to matter much less because of technological advances, Japanese cabinet members and senior bureaucrats had lost access to such US technology during the late 1930s and the Pacific War (1941-1945). However, oil by then had exploded in importance for the Japanese government's decision to continue the war in China (1937-1945), considering that ultimately US-Dutch-British sanctions were the Tōjō Hideki government's main reason for seizing the Indonesian oil wells and going to war with the United States and the Dutch government-in-exile. Knowledge about the growth of US oil production offshore of California and in the Mississippi River Delta was certainly a given. For example, related to the struggle between the federal government and several US states about legal control over offshore oil fields,

\footnotetext{
${ }^{36}$ Ibid., 47-52; Dwight Kempton, 'The Drilling of Submarine Oil Wells as Performed at Summerland, Cal.,' Scientific American (18 January 1902): 36.

${ }^{37}$ Compare images from 1896 and 1900: 'Echigo Amase-machi sekiyukō. Amaze [sic] Petroleum Wells, Echigo,' Taiyo 2, no. 7 (1896): n.p.; Noguchi, Chiri shashinchō, 10.

${ }^{38}$ Preben Oldenburg, 'Current Practices in Maritime and Water-Bed Drilling,' Oil and Gas Journal (17 April 1941): 72-3, 104, 106. On new seismic refraction exploration, see Tyler Priest, The Offshore Imperative. Shell Oil's Search for Petroleum in Postwar America. $2^{\text {nd }}$ ed. (College Station: Texas A\&M University Press, 2010), 31.

${ }^{39}$ Roy E. Leigh, 'Foreign Pipe Line Projects Will Test Skill of Engineers,' Oil Weekly 61, no. 8 (1931): 55-8, 60, 64, 107; C. O. Wilson, 'Only Production in Egypt Comes from two Fields on Suez Gulf Shores,' Oil and Gas Journal (8 December 1945): 62-5; Yvan Barreto de Carvalho, 'Offshore Operations in Brazil,' Offshore (July 1960): 13; 'Drilling Records Established in Maracaibo Lake Drilling,' Oil Weekly 55, no. 13 (1929): 82-8. On Burma and Brunei, see below.

${ }^{40}$ Richard J. Samuels, The Business of the Japanese State: Energy Markets in Comparative and Historical Perspective (Ithaca: Cornell University Press, 1987), 171-4.
} 


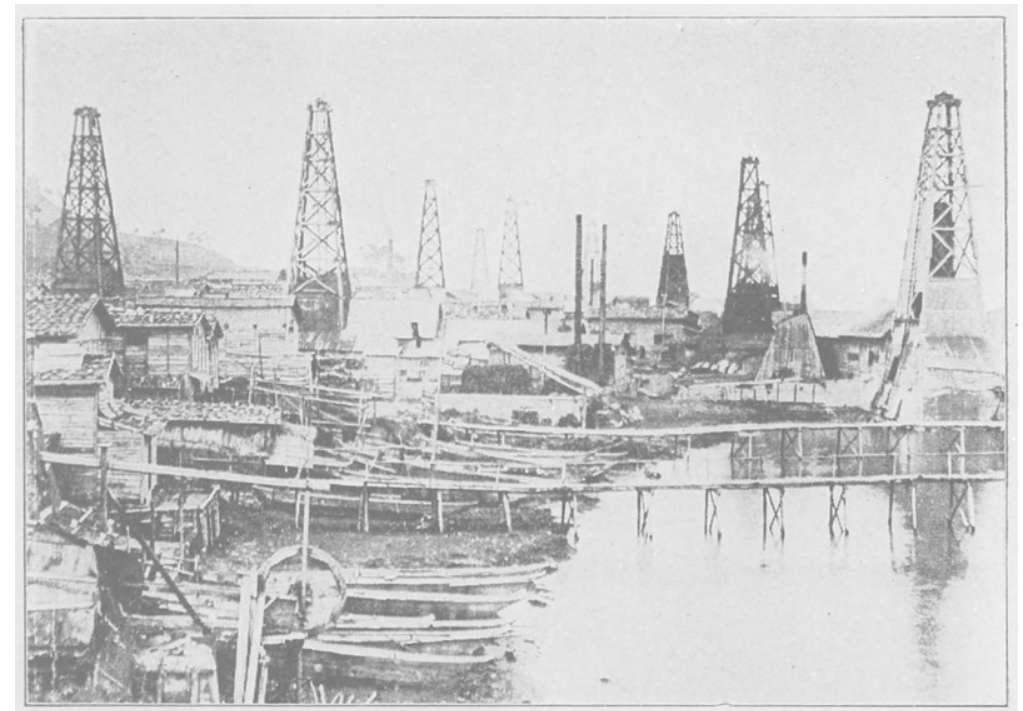

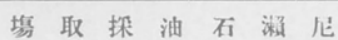

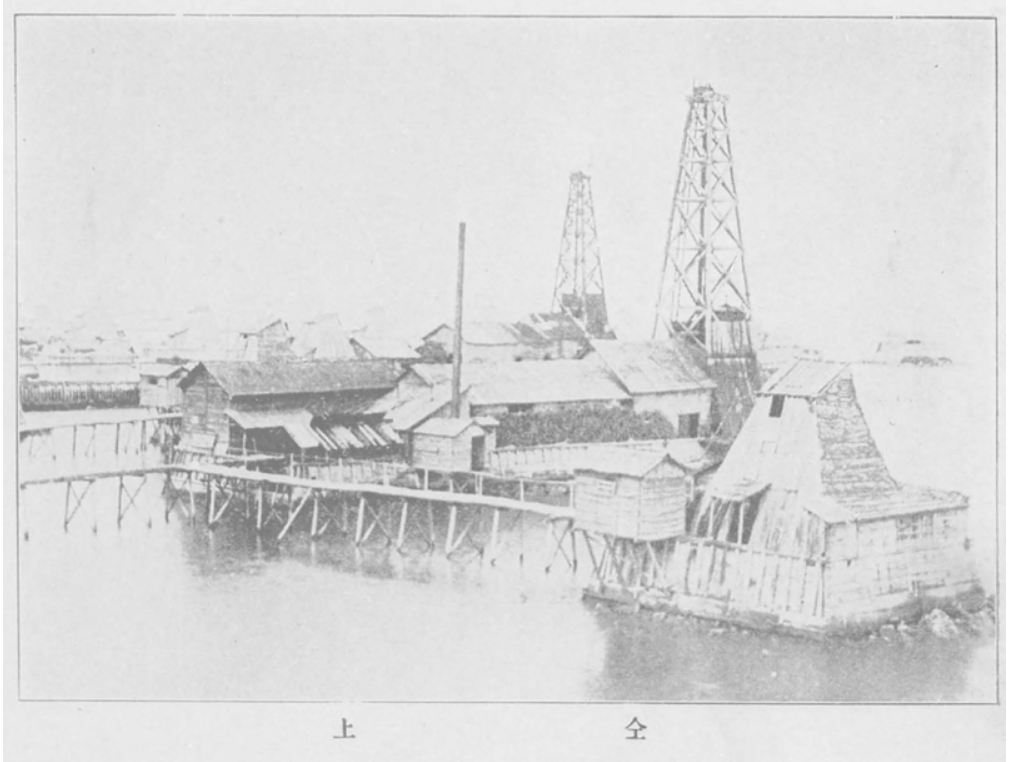

Figure 1. Coastal drill sites and pier-connected, sheltered offshore drill sites in the Amase oil mining area (1900). Source: Noguchi, Chiri shashinchō, 10.

US Representative Sam Hobbs (Democrats, Alabama) criticized in Congress in March 1939 that the 'vast bulk of the oil now being extracted [from California's offshore wells] is being sold to Japan and Japan has as much right to buy as any other purchaser, but we need that oil [for a US Navy reserve]'. ${ }^{41}$ Even without such attention-catching statements aimed at denying oil sales to Japan, Japanese political elites knew through the companies involved in importing Californian

\footnotetext{
${ }^{41}$ 'Oil at the Capitol,' Oil Weekly 93, no. 3 (1939): 62.
} 


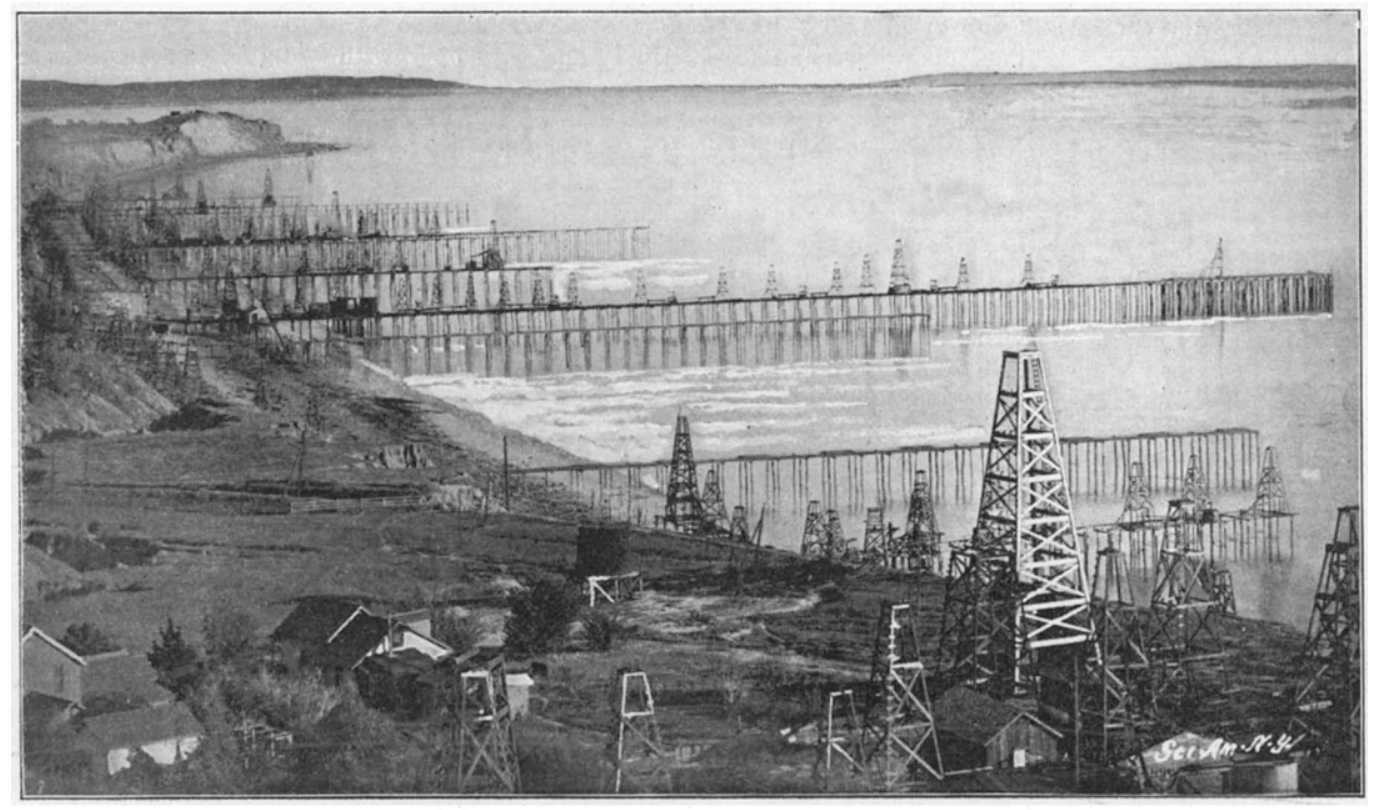

Figure 2. Beach drill sites and pier-based offshore drill sites in Summerland, California (1902).

Source: Dwight Kempton, 'The Drilling of Submarine Oil Wells as Performed at Summerland, Cal.,' Scientific American (18 January 1902): 36.

oil about its origins_-not to mention that professional oil industry journals over the course of decades had published about technological advances. ${ }^{42}$

When WWII was over, the attempts by Japanese oil experts to slightly improve the empire's increasingly desperate oil situation through offshore drilling had resulted in nothing. For example, in occupied French-Indochina, oil seeps had been spotted in 1944 at low tide on the surface of a lagoon (Đầm Thị Nại) adjacent to the coastal city of Qui Nhon (Quy Nhơn) in central Vietnam. It resulted in exploratory drilling on both shores and, through use of a pontoon (a hollow, airtight, and thus floating structure), in the lagoon. For sure, the apparent lack of geophysical surveying equipment and exploration knowledge was a problem, since otherwise it would have been known that there was no oil field and no reason to do exploratory drilling. ${ }^{43}$ Another example was British Burma, where the Burmah Oil Co.'s and Indo-Burmah Petroleum Co.'s wells were destroyed and thus denied to the invading Japanese military. ${ }^{44}$ The vast majority of Burma's contemporary oil wells were located along the banks of the Irrawaddy River. Before British colonialism, the upper Burmese (Kingdom of Ava) oil industry that exploited some of these riverside fields had relied on the Irrawaddy for shipping. ${ }^{45}$ When British companies increasingly became involved in Burmese oil production near the end of the nineteenth century, the river remained for some time the only

\footnotetext{
${ }^{42}$ See the references in footnote 39.

${ }^{43}$ A report from 1957 identified a minimal layer of plant debris-rich mud $20 \mathrm{~cm}$ below the surface as the oil trace's origin: Edmond Saurin and Henri Fontaine, Carte géologique 'Viet Nam, Cambodge, Laos' à l'échelle du 1:500.000 [Geological maps of Vietnam, Cambodia, Laos at a scale of 1:500.000]. Vol. 15: Notice sur la feuille du Qui Nhon [Note for the sheet on Qui Nhon] (Dalat: Service géographique national du Viet Nam, 1964), 51-2.

${ }^{44} \mathrm{H}$. R. Tainsh, 'Tertiary Geology and Principal Oil Fields of Burma,' Bulletin of the American Association of Petroleum Geologists 34, no. 5 (1950): 823-55, here 823-4.

${ }^{45}$ Sujit Sivasundaram, 'The Oils of Empire,' in Worlds of Natural History, eds. Helen Curry et al. (Cambridge: Cambridge University Press, 2018), 379-98; Andrew Racey and Michael F. Ridd, 'Historical Background to Myanmar's Petroleum Industry,' Geological Society, London, Memoirs 45, no. 1 (2015): 13-20.
} 


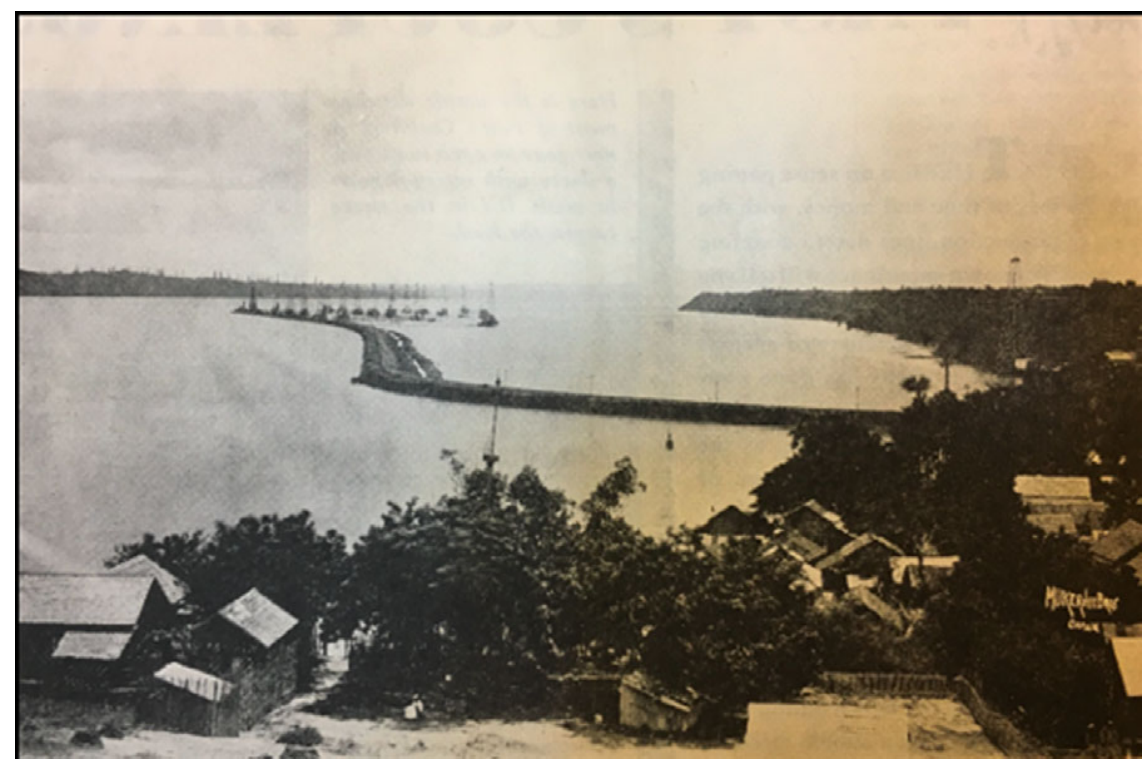

Figure 3. The photo caption reads 'Indo-Burmah Petroleum Company's drilling operations in the bed of the Irrawaddy River, Lanywa, Upper Burma.' One can see the reclaimed dyke wall, which strongly reduced water movement in the west bank, and in the background the offshore oil derricks (1932). Source: Photo. Oil Weekly 65, no. 4 (1932): 40. Courtesy: Oil Weekly.

practical transportation route between Rangoon, Mandalay, and other markets. This oil field geography again emphasized how important the contingency of locations was, which for economically feasible production in light of the absence of a local market needed proximity to waterways for long-distance transportation, before transportation of equipment and oil through roads, railways, or early pipelines became available. Simultaneously, local physical geography had to enable offshore drilling. At the Lanywa field (located like the bigger Chauk field near the town of Lan Ywar in upper Burma), where the Irrawaddy was about 1.6 kilometres in width, Indo-Burmah Petroleum Co. in 1925 and 1926 had walled off part of the river's west bank through a dyke reclamation project. Constructing this reclaimed dyke wall had caused substantial engineering problems related to the summer monsoon, when strong rainfall meant that the river could rise by more than 12 metres above average and its flow accelerate to $9 \mathrm{~km} / \mathrm{h} .{ }^{46}$ Afterwards, emphasizing the global technological connections, the company used designs developed in the United States' watery regions. Derricks were set up on piers that enabled drilling in the walled-off, slow-moving waters (see Figures 3 and 4). During the occupation, the Japanese managed to produce a very limited amount of oil at the fields, but it must be assumed that lack of technology, resources, and knowledge meant that they tapped the least damaged and most accessible terrestrial wells. ${ }^{47}$

Altogether, field locations and their physical geographies, the global trajectory of offshore oil technology advances, and ultimately dwindling access to such technology meant that after Japanese oil companies had set Asia's first offshore oil project into motion near the end of the nineteenth century, Japanese political elites for decades played no role in moving Asia's waters into the Anthropocene. Rather, agency rested with several private British oil companies,

\footnotetext{
${ }^{46}$ Tainsh, 'Tertiary Geology,' 843-4; T.A.B. Corley, A History of the Burmah Oil Company, Vol. 2: $1924-66$ (London: Heinemann, 1988), 52-3.

${ }^{47}$ See the reports, which mainly concern bigger fields like Chauk, in: 'Burma: Claims for Denial, Damage, Oil and Stocks Taken Over,' POWE 33/659, National Archives, Kew, UK.
} 


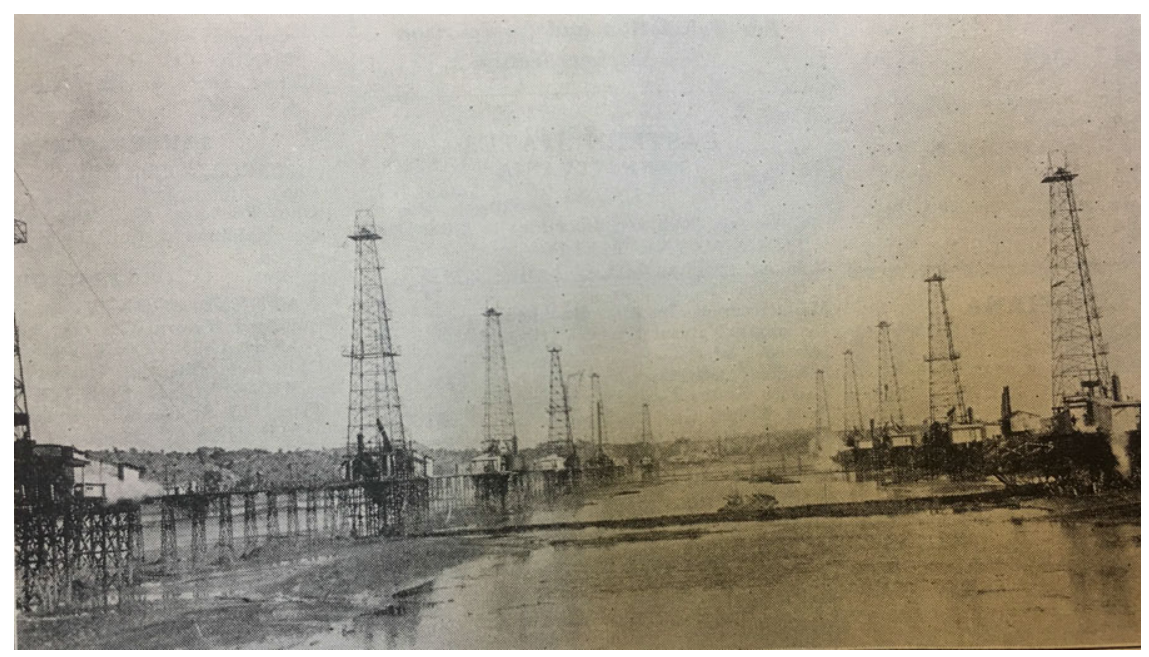

Figure 4. Closer look at some of the offshore oil derricks set up on piers, while the dyke wall can be seen to the left (1931). Source: Photo. Oil Weekly 62, no. 6 (1931): 61. Courtesy: Oil Weekly.

operating in the colonial frameworks that shaped Burma and Brunei, as will be briefly shown below. This contrast is important to understand the radical shift toward Asian political elites' agency when decolonization-and Japan's postwar international reintegration—allowed it.

\section{The growing role of Asian political elites}

There are strong indications that with access to US technology, Japanese wartime political elites would have been able to extract oil from new offshore wells. In August 1952, a few months after the allied occupation had ended in April, Tōhoku University received an oil sample for analysis. ${ }^{48}$ What indeed was oil was the result of a postwar offshore exploration endeavour off Akita Prefecture in northwest Honshu. Small oil fields along the coastline near Akita City had been discovered and exploited since the late nineteenth century, indicating that (similar to Niigata Prefecture) there were offshore fields located below the Sea of Japan. The exploration technologies used by the prospectors were based on those that had emerged in Louisiana's bayous. Similar to submersible drilling barges designed since 1928, which hosted a derrick on top of a substructure straddling two floating units, the prospectors connected two boats, the drilling equipment elevated between them. In ten-metre-deep water, they struck oil about 27 metres below the seabed. While the related newspaper article is not very detailed, the water depth was within the exploratory drilling and production reach that US oil companies had achieved during the mid-1930s. ${ }^{49}$ The discovery, arguably made more than one and a half decades after it could have been made and exploited, demonstrated that importing globally circulating US technology would enable largescale exploration projects in the waters off Asia's terrestrial oil regions.

Without doubt, another such demonstration was British Malayan Petroleum Co. (owned by Royal Dutch Shell) in 1953 announcing its offshore expansion in British-controlled Brunei.

\footnotetext{
${ }^{48}$ Kaitei kara sekiyu saishu [Extracting oil from the seafloor],' Asahi Shimbun (Morning edition, 19 August 1952 ): 3.

${ }^{49} \mathrm{Ibid}$. The floating construct only had to deal with a short drilling depth, compared to the more than two kilometres that submersible drilling barges could drill, which after flooding rested on the ground and thus were far more stable; see 'Sea-Going Oil Derricks in South Louisiana,' Oil Weekly 51, no. 12 (1928): 128. Drilling barges operating in quiet US waters while floating had been designed since 1932; see: Brad Mills, 'Marshy Conditions at Lake Washington Require Unique Drilling Procedure,' Oil Weekly 73, no. 8 (1934): 21-3. Pier construction had reached waters 12 meters deep off California in 1931; see Lawrence B. Collins, 'Drilling in Pacific Requires Substantial Foundation,' Oil Weekly 60, no. 8 (1931): 24-6.
} 
Gas seepages had led the company to the discovery of the Seria oil field in 1929, located close to the western border in a mangrove swamp near the stream of the same name and the coastline. In particular during the winter monsoon season, flooding due to heavy rainfall had occasionally occurred, despite the millions of tons of sand that had been spread over the area to raise it about one metre. The seasonality of flooding and the focus on muddy ground nevertheless meant that no adaptation to aquatic drilling conditions took place. Global technological connections became relevant only in 1933, when a US-style pier featuring one derrick was built into the South China Sea, followed in 1936 by four derricks set up on a second, heavier and longer piling. Further projects were nevertheless limited to using new directional drilling technology that enabled drilling from beach sites into the earth below near-shore waters. ${ }^{50}$ The rough waves during the winter monsoon season-especially during December and January-likely meant that the two wooden piers served test purposes, and the pier option was not pursued further for the time being. ${ }^{51}$ However, following the announcement made during the previous year, the South China Sea's first fixed offshore platform was towed to its destination and installed in 1954. The platform used a much more robust steel jacket design that had been developed during the second half of the 1940s for the rough open waters of the Gulf of Mexico, enabling it to withstand Brunei's winter monsoon surges. $^{52}$

This example of the increasingly global use of platforms designed for open waters must have further encouraged the Japanese government to accelerate exploration of Japan's and other waters. In late 1954, when the Hatoyama Ichirō administration was formed, this aim became a topic in the discussions regarding postwar Japan's first Five Year Plan (1956-1960). Accordingly, in December 1955, when the Plan was finalized, a semi-public company - the Finance Ministry held the majority of shares-was founded and tasked with exploring and developing new fields, the Japan Petroleum Exploration Co. (JAPEX; Sekiyu Shigen Kaihatsu K.K.). One of JAPEX's main concerns was to import offshore oil technology. ${ }^{53}$ This concern also illustrates that several Asian governments eventually turned geophysical surveying, platform construction, and maintenance into parts of their national development plans. In Japan, the first platform was built in 1959, as will be discussed below, and in Singapore in $1969 .{ }^{54}$ This trend was later followed by further countries, such as China and South Korea during the 1980s. Several Asia-based companies thus eventually contributed to technological advances and reduced the importance of platform and equipment manufacturers located in the US Gulf of Mexico.

State-supported exploration projects and governmental appropriations of marine spaces since the mid-1950s show that Asian political elites now began to guide the succeeding wave of offshore fossil fuel development projects. While oil fields located on land directly next to bodies of water had once been indicators of possible fields offshore, US technology enabled exploration of far larger and also more distant marine spaces, resulting in the acceleration that characterized the oceanic Anthropocene. In terms of relational space, aquatic transportation of imported equipment and export of oil to markets, such as Japan, remained a facilitator compared to yet unconnected parts of terrestrial Asia. The Japanese government thus not only focused on Japan's waters but also became the main importer and a major financer of projects in other parts of Asia. Simultaneously, the accessibility of marine spaces by offshore oil industry vessels, including platforms towed over very large distances, meant that, in contrast to terrestrial development projects, the agency of Asian political elites was hardly reduced by physical infrastructure-related structural choice limitations going back to decisions made during colonial rule. I emphasize this point of state-led

\footnotetext{
${ }^{50}$ G. C. Harper, The Discovery and Development of the Seria Oilfield (Bandar Seri Begawan: Star Press, 1975), 2, 4-5, 25, 48.

${ }^{51}$ For an overview of all sorts of wave-caused damages, see ibid., 25.

${ }^{52}$ Ibid., 48-9; 'Offshore Drilling Begun in the South China Sea', World Oil 136, no. 7 (1953): 272-3.

${ }^{53}$ Tairikudana Sekiyu Kaihatsu Kyōkai, ed., Nihon no kaiyō sekiyu kaihatsu [Japanese Offshore Oil Development] (Tokyo: Tairikudana Sekiyu Kaihatsu Kyōkai, 1985), 1, 28; Samuels, The Business, 193-4; 'Japan,' Offshore (22 August 1958 ): 43.

${ }^{54}$ Tairikudana Sekiyu Kaihatsu Kyōkai, Nihon, 28; Weng Hoong Ng, Singapore, the Energy Economy: From the First Refinery to the End of Cheap Oil, 1960-2010 (New York City: Routledge, 2012), 86-93.
} 
offshore fossil fuel developmentalisms and military-related energy security fears by contrasting the governmental agendas and marine space appropriations after decolonization with the earlier projects. The aforementioned earlier offshore drilling had taken place since the late nineteenth century within the already claimed territorial waters of Japan and Brunei (or in a Burmese river). The Japanese government now provided funding to fully explore the archipelago's territorial waters. Moreover, what also emerged during the 1950s and 1960s was state-led, large-scale marine space appropriation that stretched from the continental shelf of the Persian Gulf to the South China Sea and further north. After all, in terms of legal frameworks, structural choice limitations did not inhibit this development. The spatial appropriation and the new legal regimes that Asian political elites could create thus emphasize their agency vis-à-vis oil companies, whether private or public.

Starting with the task of importing technology, JAPEX purchased a jack-up rig design, which had been developed for use in the US Gulf of Mexico. In contrast to the fixed platform off Brunei, the jack-up rig, 'Hakuryūgō,' had evolved from submersible drilling barges that had been designed to operate in Louisiana's bayous. 'Hakuryūgō' was able to float while being towed to its destination, where its legs would be submerged to stabilize it by penetrating the seabed. The mobile design enabled it to do exploratory drilling at various locations, which underlines the limited physical infrastructure needs for the large-scale project. The Japanese government in the process subsidized JAPEX's increase in offshore exploration capability, a consequence of the aforementioned oil scarcity problems caused by limited Japanese capabilities before and during WWII. Simultaneously, the decision was a reminder of global maritime connections, since alternatively a platform could have been towed from the US Gulf Coast to Japan. After construction by a Japanese heavy industry company, 'Hakuryūgō' began its work off Akita Prefecture in April 1959. ${ }^{55}$ In November, the platform discovered what would be named the Tsuchizaki offshore oil field, located off Michikawa and very close to Akita City, followed by more discoveries nearby during the following months. ${ }^{56}$

Japanese offshore oil fields were marginal in size compared to those found in major oil regions, but an almost simultaneous, Japanese government-supported project discovered a huge offshore field and accelerated the energy transition in the waters of the Persian Gulf. In the postwar period, the Persian Gulf and its coastal areas became the most important oil region-and here again the presence of terrestrial oil fields made discoveries offshore likely. In 1951, US oil company ARAMCO (Arabian-American Oil Co.) found an offshore oil field off Saudi Arabia, the first to be confirmed in the comparatively shallow waters of the Gulf. ${ }^{57}$ The event attracted the attention of Japanese political and economic elites, among them businessman Yamashita Tarō, who had very good contacts to Kishi Nobusuke's cabinet. During the early economic high-growth period, Yamashita developed a plan to produce and sell offshore oil from the Persian Gulf to Japanese customers, since hardly any other oil concessions were globally available. ${ }^{58}$ After long negotiations between February 1957 and July 1958, Yamashita's newly founded Arabian Oil Co. (Arabia Sekiyu K.K.) gained a newly created offshore concession in the waters off the Saudi Arabia-Kuwait Neutral Zone. ${ }^{59}$ Using jack-up rigs built in the US Gulf of Mexico and towed across the ocean, the very substantial Khafji oil field was discovered in January 1960. Before that,

\footnotetext{
${ }^{55}$ 'Kaitei yuden o kaihatsu [Developing offshore oil fields],' Asahi Shimbun (Morning edition, 16 April 1958): 4; 'Kaitei no yuden o saguru [Searching for offshore oil fields],' Asahi Shimbun (Morning edition, 1 April 1959): 10.

${ }^{56}$ Kaitei paipurain no kaitsūshiki [Opening of subsea pipeline],' Asahi Shimbun (Morning edition, 23 October 1960): 10; Samuels, The Business, 194.

${ }^{57 ، O f f s h o r e ~ O i l, ' ~ O i l ~ a n d ~ G a s ~ J o u r n a l ~(14 ~ J u n e ~ 1951): ~} 68$.

${ }^{58}$ Masanari Koike, Gento Mogi, and Waleed H. Albedaiwi, 'Overseas Oil-Development Policy of Resource-Poor Countries: A Case Study from Japan,' Energy Policy 36, no. 5 (2008): 1764-75, here: 1766, 1769-70.

${ }^{59}$ 'Zadankai: sekiyu jigyō no kaigai shinjutsu [Roundtable discussion: The oil business' advance into overseas markets],' Gaikō jihō 970 (1960): 40-51, here: 41, 47; Ryū Funakoshi, 'Arabia-wan ni okeru chūritsu chitai okiai yudan no kaihatsu' [On the development of the offshore oil field in the Saudi-Kuwaiti Neutral Zone in the Persian Gulf], Nenryō kyōkaishi 39, no. 404 (1960): 841-8, here: 841-2.
} 
an explosion in July 1959 had not only largely destroyed a platform but also indicated the presence of the oil field, after which the Kishi government provided huge amounts of funding: USD 42 million before the end of the year, while Minister of International Trade and Industry Ikeda Hayato (in 1960 becoming prime minister) proposed another loan of USD 175 million for Arabian Oil's future development of the field. ${ }^{60}$ Several years later, in 1966, the company's offshore wells contributed a very noteworthy $14 \%$ to Japan's oil imports. ${ }^{61}$

In terms of the growing agency of West Asian or Middle Eastern political elites, Saudi finance minister Mohammed Suroor Sabban, oil director Abdullah Tariki, and their Kuwaiti colleagues were able to receive substantially better conditions from Yamashita's company than Western major oil companies had previously offered them. Publicly gaining greater leverage in negotiating conditions-here concerning a newly created concession made possible by the appropriation of marine space in the first place-supported the governments in their endeavours to decolonize their oil industries. ${ }^{62}$ Such decolonization also resulted in Saudi Arabia and Kuwait becoming two founding members of the Organization of the Petroleum Exporting Countries (OPEC) in 1960 and culminated in the drastic oil price increase of 1973. Moreover, the Saudi and Kuwaiti negotiations with Arabian Oil Co. and the company's discovery success encouraged other Asian governments to appropriate marine spaces beyond their territorial waters by proclaiming legal control over the continental shelf and its oil resources. Such claims accelerated globally after WWII in reaction to the US Truman administration's claim in 1945 over continental shelf resources and culminated in the United Nations Convention on the Continental Shelf (1958, entering into force in 1964), through which signatory governments granted each other legal control over offshore oil exploitation wherever technology could reach it. The convention and its successors therefore created a new legal framework that granted Asian and other governments control over marine spaces that then ushered in the oceanic Anthropocene. ${ }^{63}$

In Japan's case, while the agency of capitalists like Yamashita is no way negated, the support from Japanese diplomats and governmental funding was highly important. After all, Japan in 1945 had lost its colonial empire and the Allied occupation's initial demilitarization and deindustrialization project disrupted access to oil concessions, meaning that the country possessed only marginal oil fields in its remaining territory. Moreover, the oil embargo of summer 1941 had longlasting consequences in terms of energy security fears among Japanese political elites, in many cases people who had already been active before and during the war (among them Kishi, who during wartime had led the ministries of munitions and commerce). Their fears, strengthened when the Suez Crisis (1956) had delayed oil deliveries to Europe, increased their willingness to support projects that diversified supply regions or granted Japanese companies control over production and export of oil to Japan. During the 1960s, the rapidly growing oil requirements of the high-growth economy further increased these fears. ${ }^{64}$ Together, energy security fears and demand for oil prompted Japanese political elites - as well as their Saudi and Kuwaiti counterparts-to create the developmentalist framework within which Arabian Oil Co. operated.

\section{Asia's terrestrial and oceanic energy transitions synchronizing in the Anthropocene}

The offshore focus of Asian political elites meant that Asia's terrestrial and oceanic energy transitions began to synchronize, gradually moving the temporality of Asian marine spaces into the

\footnotetext{
${ }^{60}$ 'Persian Gulf Strike Gives Jap Firm New Life,' Oil and Gas Journal (8 February 1960): 74-5.

${ }^{61}$ Koike, Mogi and Albedaiwi, 'Overseas,' 1766.

62‘The Japanese Wildcat,' Time (15 February 1960): 95; 'Saudi-Arabia, Japanese Agree on 56-44 Persian Gulf Pact,' Offshore (February 1958): 23.

${ }^{63}$ On the wave of continental shelf proclamations, see Daniel Margolies, 'Jurisdiction in Offshore Submerged Lands and the Significance of the Truman Proclamation in Postwar U.S. Foreign Policy,' Diplomatic History 44, no. 3 (2020): 447-65.

${ }^{64}$ Laura E. Hein, Fueling Growth: The Energy Revolution and Economic Policy in Postwar Japan (Cambridge, MA: Harvard University Press, 1990), 285-309; Samuels, The Business, 195; Koike, Mogi and Albedaiwi, 'Overseas Oil-Development,' 1766.
} 
fossil fuel economy associated with the Anthropocene epoch that transformed local Asian energy regimes, albeit at different speeds. Driven by the Japanese high-growth economy's exploding demand for oil, energy security fears, and their respective own fossil fuel development projects, the newly independent governments in Southeast and East Asia began to appropriate marine spaces and to create legal regimes for offshore oil exploration.

In their attempt to discover possible offshore oil fields, political elites in independent Indonesia faced a situation not genuinely different from wartime Japan. Terrestrial oil wells had been commercially exploited since the 1880s, but their locations and geographical conditions had not resulted in any offshore drilling, neither during Dutch colonialism nor during the Japanese occupation. After the end of the independence war (1945-1949), with the intention to decolonize Indonesia's economy, the parliament passed a motion in 1951 that prohibited the granting of further concessions until a new oil law was created. In 1960, this new law permitted transnational oil companies to operate only as contractors of national oil companies. However, during the last years of Sukarno's rule, Indonesia's first president from 1945 to 1967, transnational oil companies increasingly saw their earnings dwindle and feared nationalization. The left-leaning government's economic development policies contributed to massive inflation and also enforced domestic oil sales at a very low price with the intention of democratizing consumption. ${ }^{65}$ Access to the global offshore oil exploration network was thus inhibited first by the government not offering concessions and from 1960 by the strong reluctance of transnational oil companies to invest capital and provide technology. In 1964, negotiations regarding an offshore concession began, which nevertheless dragged on until Sukarno lost his influence after October 1965. The political elite of the new Suharto regime then saw offshore oil concessions as a way to increase tax revenues and reduce the rapid inflation. Ibnu Sutowo, a military officer who served as head of the national oil company Permina (in 1968 merging into Pertamina) and from 1966 as minister of mines, encouraged the involvement of transnational oil companies through production sharing agreements between them and Pertamina. The result was that marine spaces from north Sumatra to east Kalimantan were turned into concessions and experienced an exploration rush by Japanese, US, Australian, Canadian, and European oil companies. In October 1970, the first offshore production platform was dedicated. ${ }^{66}$ The comparatively short distance across the ocean to the Japanese market meant that the majority of oil was exported there. Altogether, the trajectory emphasizes the significance of the laws and legal framework created by Indonesian political elites.

The creation of the Committee for Co-ordination of Joint Prospecting for Mineral Resources in Asian Offshore Areas (CCOP) illustrates the importance of offshore oil in the context of implementing inter-governmental development projects. In that sense, offshore oil exploration and production became an item on the political and economic agendas of global organizations, such as the UN, and their regional suborganizations. In November 1965, an expert group of the United Nations Economic Commission for Asia and the Far East (ECAFE) decided to set into motion a first surveying project. In 1966, they created the CCOP and gained assistance from several Western governments. Its delegates represented Japan, South Korea, Taiwan, and the Philippines, the three noncommunist countries geographically (and in terms of transport distance) closest to Japan, who had gained their independence after WWII. By 1974, South Vietnam, Thailand, Cambodia, Malaysia, Indonesia, and Singapore had joined this group of Asian countries bordering the West Pacific Ocean. ${ }^{67}$ The countries located around the Indian Ocean-where most offshore fields were

\footnotetext{
${ }^{65}$ Anderson G. Bartlett III et al., Pertamina: Indonesian National Oil (Jakarta: Amerasian, 1972), 1, 6; Alex Hunter, 'The Indonesian Oil Industry,' Australian Economic Papers 5, no. 1 (1966): 59-106, here: 74, 89-95; H. T. Brundage, 'Indonesian Politics Holds Key to Future Oil Progress,' World Oil 143, no. 6 (1956): 210-4.

${ }^{66}$ Bartlett, Pertamina, 4-5, 282-7, 292-5, 333; Louis Kraar, 'Optimistic American, Japanese, and European Companies Are Pressing an all-out Hunt for Oil off the Coasts of Indonesia and Neighboring Countries,' Fortune (March 1970): 45-6.

${ }^{67}$ Committee for Co-Ordination of Joint Prospecting for Mineral Resources in Asian Offshore Areas, ed., Report of the First Session ([Tokyo]: Geological Survey of Japan, 1966), 1-2; Committee for Co-Ordination of Joint Prospecting for Mineral Resources in Asian Offshore Areas, ed., Report of the Tenth Session (Bangkok: ECAFE, 1974), 1; Bangkok to Department
} 
located in inaccessibly deep water, with the exception of the Persian Gulf, a few fields off India (such as Bombay High off Mumbai, discovered in 1965), and the most western part of Indonesian waters-planned to form another group, which never happened. ${ }^{68}$

Some of the long-term results of the CCOP's first survey project are very well-known globally, involving the world's most notorious maritime boundaries conflicts. Toward the end of the UN's first global 'Decade of Development', a group of surveyors from Japan, South Korea, Taiwan, and the United States surveyed the East China Sea and the Yellow Sea between October and November 1968. What follows is the strongest illustration of Asian governments' predominant position in the oceanic Anthropocene, exemplified by them claiming control over offshore oil production and denying it to each other and corporate capitalists. The doubtlessly most important sentence in the survey report, published in 1969, reads as follows: 'A high probability exists that the [East China Sea's] continental shelf between Taiwan and Japan may be one of the most prolific oil reservoirs in the world'. ${ }^{69}$ A couple of sentences later, readers learned about the lower, but still substantial, economic potential of the Yellow Sea: 'A second favourable area for oil and gas is beneath the Yellow Sea where three broad basins are present. ${ }^{70}$ In the case of the East China Sea, the survey was the main reason for the emergence of the Senkaku/Diaoyu Islands conflict between the governments of Japan, Taiwan, and China, still festering to this day and threatening global security. After all, due to the large-scale appropriation of marine space that was underway, control over these islands would define legal control over the surrounding continental shelf far beyond territorial waters, including some of the hoped-for fossil fuel fields. The administration of US President Richard Nixon was unwilling to get involved in the conflict. In 1970, it informed US companies operating in Taiwanese concessions, disputed by Mao Zedong's government, that their vessels could not expect US naval protection. For US companies, the conflict between Chinese and Taiwanese political elites thus caused their withdrawal. Analytically, in terms of the parties dominating the conflict, this withdrawal emphasized that the US companies had very limited agency. Territorial disputes between Chinese and Taiwanese political elites with their Japanese counterparts also regularly re-emerged during the following decades. ${ }^{71}$

In the Yellow Sea, South Korea's Park Chung-hee government immediately began to award concessions. However, over the course of the following years, the Chinese government emphasized China's conflicting boundary claims through sabotage and military threats. Mao's administration also proved unwilling to participate in negotiations. The South Korean government, like many others, founded a national oil company, the Korea National Oil Corporation (Hanguk Seogyu Gongsa), and eventually shifted focus and operations to undisputed marine spaces. ${ }^{72}$ Even though not a result of the CCOP report, the ongoing South China Sea conflict, largely sparked by offshore oil exploration and constituting another threat to global security, should also be mentioned here among these maritime boundaries conflicts. ${ }^{73}$ Altogether, corporate capitalism was definitely no guiding force during this transition of parts of the South China Sea, East China Sea, and Yellow Sea into the oceanic Anthropocene and Asia's corresponding climate change narrative.

of State, ECAFE_-Preparatory Meeting for Establishing Coordinating Body for Off-shore Prospecting in Countries Bordering the Indian Ocean, 11 June 1969, in Box 2883, RG 59: General Records of the Department of State, Central Foreign Policy Files, 1967-1969, National Archives and Record Administration II, College Park, MD, USA.

${ }^{68}$ United Nations, Economic Commission for Asia and the Far East, ed., Annual Report (29 April 1969 - 27 April 1970 (New York: UN, 1970), 40.

${ }^{69}$ Kenneth O. Emery et al., Geological Structure and some Water Characteristics of the East China Sea and the Yellow Sea ([Tokyo]: Geological Survey of Japan, 1969), 41.

${ }^{70} \mathrm{Ibid}$.

${ }^{71}$ Selig S. Harrison, 'Seabed Petroleum in Northeast Asia: Conflict or Cooperation?,' in Petroleum in Northeast Asia: Conflict or Cooperation?, ed. Selig S. Harrison (Washington: Wilson Center, 2005), 3-14, here 6-10; Mark Valencia, Offshore NorthEast Asia: Oil, Gas and International Relations (London: Economist Intelligence Unit, 1988), 17-9.

${ }^{72}$ Harrison, 'Seabed Petroleum,' 11-2.

${ }^{73}$ Corazón M. Siddayao, The Off-Shore Petroleum Resources of Southeast-Asia: Potential Conflict Situations and related Economic Considertations (Kuala Lumpur: Oxford University Press, 1978), 76-101, especially 83-94. 
In the case of China, similar to many other Asian countries, field locations and their physical geographies had not encouraged an early political interest in offshore oil. When US technology enabled the exploration of the Gulf of Mexico's bays in the late 1930s, the war against Japan (which controlled the coastline) and later the Cold War tensions with the United States had inhibited the changing Chinese governments from engaging in an exploration programme. Another major problem of physical geography was related to the USSR, China's main ally after the communist victory in the Civil War in 1949. Starting the same year, the Soviet oil industry began to develop massive production infrastructure off Baku in the nontidal waters of the Caspian Sea. The large oil fields discovered after WWII in the Volga Basin and in West Siberia nevertheless meant that research attention was given to swampy or permafrost regions and not to developing platforms and equipment for exploration in rougher, open marine waters. Moreover, Western export restrictions to the USSR and China constituted another political factor in facilitating and inhibiting the global expansion of offshore oil drilling. From 1948, Western companies were only allowed to sell such technology if permitted by their governments, which usually was not the case due to oil being a strategic resource in the global Cold War. ${ }^{74}$ Chinese political elites were thus unable to obtain any open marine waters technologies from the USSR before relations between the two countries strongly deteriorated in the 1960s, Soviet technicians were withdrawn, and Chinese self-reliance advocacy intensified. Only during the early 1970s did the Mao government begin its own statecontrolled exploration activities. The initial focus was primarily on the Bohai Sea, realized through the purchase of offshore oil technology during a time of rapprochement with the United States and Japan. By the late 1970s, further reopening of the country also resulted in joint venture agreements with transnational companies. ${ }^{75}$ However, in China's case, as in almost all other parts of Asia, it was strong state control and governmental economic planning, and not freely acting corporate capitalists, that steered the marine spaces' energy transition into the oceanic Anthropocene.

\section{Conclusion}

The oceanic dimension of the Anthropocene cannot be understood adequately without considering the local trajectories of intensifying global offshore oil exploitation, which since the 1950s caused Asia's terrestrial and oceanic energy transitions to synchronize in this new epoch. Offshore oil production originated in Honshu about the same time that it emerged in Southern California. The absence of oilbearing bayou-like waterscapes in Japan and other Asian countries nevertheless did not encourage a continuous development of technology for increasingly deeper and rougher waters, in this way disconnecting Asia's terrestrial and offshore oil fields from each other. In certain Asian regions, local environmental conditions like monsoon-driven rough waves also made aquatic drilling conditions less appealing than in the much calmer bayous and therefore inhibited a faster intensification of global technological connections. When US open waters technology was eventually transferred to Asia during the 1950s, decolonization was already in full swing. Large-scale offshore oil exploitation beginning in most of Asia's coastal countries only after their independence and being implemented by Asian political elites was thus, to a large degree, a result of contingent field locations that here featured unfavourable physical geographies. However, political factors, such as military conflicts, Cold War tensions, or economic decolonization, also extended the divergence, in particular after growing exploration and production reaches by US companies had made yet unknown fields theoretically discoverable. Corporate capitalists therefore were no dominant force. Rather, the Asian political elites'

\footnotetext{
${ }^{74}$ Mir-Babaev, Kratkaia, 169; Steve LeVine, The Oil and the Glory. The Pursuit of Empire and Fortune on the Caspian Sea (New York: Random House, 2007), 50-2; Donald R. Bakke, 'Russia's Caspian Activity Drops as Sea of Azov Begins First Production,' Offshore (20 June 1976): 201-14.

${ }^{75}$ Kenneth Lieberthal and Michel Oksenberg, Bureaucratic Politics and Chinese Energy Development (Washington: United States Department of Commerce, 1986), 177-89; Kim Woodard, The International Energy Relations of China (Stanford: Stanford University Press, 1980), 203-6; 'China Develops Oil Play but Keeps Figures a Secret,' Offshore (November 1976): 232 .
} 
developmentalist agendas transcended claims of corporate capitalism as the defining cause of climate change while at the same time also drawing attention to communist systems. Likely, one can find similar patterns in other marine regions-I do not claim that the role of political elites discussed here was unique to Asia.

The Asian political elites' agency was strongly supported by the characteristics of marine spaces. These marine spaces were shaped by global developments in the realms of technology and international law, but - in contrast to terrestrial spaces - the related offshore development projects were hardly affected by infrastructure- or law-related structural choice limitations due to the legacies of colonialism. This point is illustrated by the Asian political elites' new appropriation of marine space, creation of legal regimes, and integration of the large amount of newly gained offshore oil-bearing oceanic ghost acres into their respective developmentalist agendas. These characteristics of marine spaces, in addition to marine access to the Japanese market and its growing demand for oil, are also what united this group of Asian political elites and their offshore fossil fuel developmentalisms.

What does this strong agency of political elites tell us about the future of the ocean in Asia's Anthropocene and the global energy transition toward renewable energy sources? After terrestrial and oceanic energy transitions synchronized their temporalities through oil economies, there is no reason to assume that they will desynchronize again. In the new global energy transition toward renewable energy, solar power and-even more dependent on region-wind power are the only realistic means for long-term compensation for the power generated by fossil and nuclear power plants. ${ }^{76}$ The unrealistic spatial demand of wood and other terrestrial biofuels, for example, was mentioned earlier. As offshore oil created large amounts of oceanic ghost acres that could substitute the demand for forest space, I have little doubt that Asian governments will again aim to claim large amounts of ghost acres from the ocean for renewable energy generation to reduce terrestrial space demand-for example, for solar panels and wind turbines due to competing land uses. In the case of floating solar panels, installed since 2007, calm lake waters are reminiscent of the role that Louisiana's bayous played in the history of offshore oil. ${ }^{77}$ In the bayous, the technological advances ultimately led to the rough, open waters of the Gulf of Mexico. For floating solar, marine waters on average would allow a slightly higher energy generation than terrestrial places, adding to the appeal of offshore ghost acres for renewable energy generation. ${ }^{78}$

In that sense, future and more detailed narratives concerning the oceanic Anthropocene in Asia would have to critically reflect on the various governmental activities that have shaped and may continue to shape the offshore advance of Asian political elites. This includes governmental failures, corruption, and their reasons. To give just one example, the huge number of unsuccessful Japanese government-financed offshore oil exploratory drilling projects-with failure rates of 97$98 \%$ - came at immense cost to the taxpayer as a result of the very problematic incentive regime and related serious moral hazards that originated in the energy security fears of Japanese political elites, who were willing to cover most of the capital costs in case of failure. ${ }^{79}$ One certainly does not need similar fear-driven planning disasters in the current global energy transition.

Conflict of interest. No conflict to report.

\footnotetext{
${ }^{76}$ Smil, Energy Transitions, 110.

${ }^{77}$ World Bank Group et al., Where Sun Meets Water. Floating Solar Market Report_Executive Summary (Washington, DC: World Bank, 2018), 3-13.

${ }^{78}$ Smil, Energy Transitions, 117.

${ }^{79}$ Koike, Mogi, and Albedaiwi, 'Overseas Oil-Development,' 1767, 1769; Shigeru Suzuki, 'Kaigai sekiyu kaihatsu to Sekiyu Kaihatsu Kaidan (1) [The Japan Petroleum Development Corporation's role in developing overseas petroleum (1)],' Kagoshima Keidai Ronshū 22, no. 2 (1981): 1-23, here: 6-7.
}

Cite this article: Huebner S. 2023. Asia's oceanic Anthropocene: How political elites and global offshore oil development moved Asian marine spaces into the new epoch. Journal of Global History 18: 25-46, doi:10.1017/S1740022821000413 